\title{
INTEGRAÇÃO LAVOURA-PECUÁRIA COM A CULTURA DO FEIJOEIRO E PASTAGEM DE INVERNO, EM PRESENÇA E AUSÊNCIA DE TREVO BRANCO, PASTEJO E NITROGÊNIO
}

\author{
Amadeu Bona Filho \\ Orientador: Prof. Dr. Adelino Pelissari
}

\begin{abstract}
RESUMO
O experimento foi conduzido na Estação Experimental da Fundação Agrária de Pesquisa Agropecuária (FAPA), no município de Guarapuava-PR, no período de julho de 2000 a março de 2001. Os objetivos foram, em sistema de integração lavoura-pecuária, avaliar a influência da adubação nitrogenada, em presença e ausência de trevo branco (Trifolium repens), na produtividade da pastagem de inverno composta pela mistura de aveia branca (Avena sativa) e azevém (Lolium multiflorum) e no ganho de peso animal e por hectare. Também avaliou-se o efeito do pastejo e a contribuição do nitrogênio residual da pastagem no rendimento da cultura do feijoeiro (Phaseolus vulgaris L.) implantada após a fase de pastejo. Foram conduzidos dois ensaios em delineamento de blocos ao acaso, com parcelas subdivididas, com três repetições por tratamento. No ensaio de inverno, com novilhos machos em pastejo, foram utilizadas quatro doses de nitrogênio $\left(0,100,200\right.$ e $\left.300 \mathrm{~kg}_{\text {ha }}{ }^{-1}\right)$ nas parcelas e nas subparcelas a presença e ausência de trevo branco. No ensaio de verão, com a cultura do feijoeiro, foram utilizadas cinco doses de nitrogênio $\left(0,40,80,120\right.$ e $160 \mathrm{~kg} \cdot$ ha $\left.^{-1}\right)$ nas parcelas, sendo as subparcelas as doses de nitrogênio na pastagem e as subparcelas a presença ou ausência de trevo branco e de pastejo. A produção de forragem respondeu linearmente à aplicação de nitrogênio e não sofreu influência do trevo branco. Os ganhos de peso por animal e por hectare não foram influenciados pelo trevo branco, mas foram afetados pelo nitrogênio, porém de forma não linear. A produtividade do feijoeiro foi influenciada pelo nitrogênio na pastagem e na cultura, apresentando resposta quadrática. Somente o número de vagens por plantas apresentou resposta às doses de nitrogênio, não havendo respostas para o número de grãos por vagem, massa de 100 grãos e índice de colheita aparente. A presença do trevo branco e do pastejo não influenciou o rendimento feijoeiro. A produção de forragem e a produtividade animal foram altamente influenciadas pela adubação nitrogenada da pastagem de inverno. A adubação nitrogenada do feijoeiro pode ser dispensada quando, em siste de integração lavoura-pecuária, a pastagem é submetida a altas doses de nitrogênio.
\end{abstract}

\begin{abstract}
The experiment was carried out at Estação Experimental da Fundação Agrária de Pesquisa Agropecuária (FAPA) in GuarapuavaPR-Brazil from july of 2000 to march of 2001. In a pasture $x$ crop rotation system, the objectives were: to evaluate the influence of nitrogen fertilization with and without white clover (Trifolim repens) on a oat (Avena sativa) and italian ryegrass (Lofium muftiflorum) mixture evaluating pasture and animal production; and to evaluate the influence of grazing and residual nitrogen from grazed pasture on common bean (Phaseo/us vu/garis) yield which was sowed after grazing period. In a split plot model of a complete randomized blocks design with three replicates per treatment two trials were conducted. For the winter pasture trayl treatments were nitrogen levels $(O, 100$, 200 and $300 \mathrm{~kg} \mathrm{ha}^{-1}$ ) and presence and absence of white clover. For the summer crop trial treatments were nitrogen levels on crop (O, $40,80,120$ and $160 \mathrm{~kg}$ ha $^{-1}$ ) following pasture nitrogen levels and presence or absence of white clover and presence or absence of grazing. Pasture dry matter production increased in response to nitrogen fertilization, but was not affected by white clover presence. Live weight gain and live weight gain per hectare were affected by nitrogen, but not by white clover. Common bean yield showed positive response to nitrogen applied on pasture and on crop, but was not influenced by white clover nor grazing. Number of pods per plant was positively influenced by nitrogen and was the only responsible for differences in bean yield. Number of grains per pod, weight of 100 grains and harvest index were not influenced by nitrogen nor by white clover or grazing. Pasture dry matter production and liveweight gain per hectare are highly influenced by nitrogen fertilization. In a pasture $x$ crop rotation system, which are receiving high levels of nitrogen on pasture, the residual nitrogen from recycling during grazing period can support high bean grain productivity without using any nitrogen fertilization on crop.
\end{abstract}

Key-words: pasture $\mathrm{x}$ crop rotation, nitrogen, beef production, white clover, common bean. 